\title{
Genetic diversity of Hypostomus ancistroides (Teleostei, Loricariidae) from an urban stream
}

\author{
Silvia H. Sofia ${ }^{1}$, Bruno A. Galindo ${ }^{1}$, Francine M. Paula ${ }^{1}$, Leda M.K. Sodré ${ }^{1}$ and Cláudia B.R. Martinez ${ }^{2}$ \\ ${ }^{I}$ Departamento de Biologia Geral, Centro de Ciências Biológicas, Universidade Estadual de Londrina, \\ Londrina, PR, Brazil. \\ ${ }^{2}$ Laboratório de Ecofisiologia Animal, Departamento de Ciências Fisiológicas, \\ Centro de Ciências Biológicas, Universidade Estadual de Londrina, Londrina, PR, Brazil.
}

\begin{abstract}
In this study, random amplified polymorphic DNA (RAPD) markers were applied to analyze the genetic diversity of samples of the Neotropical catfish Hypostomus ancistroides, collected from four sites (S1, S2, S3 and S4) along an urban stream in Southern Brazil. The 11 primers used in RAPD analysis amplified 147 loci, 76 (51.7\%) of which were polymorphic. The proportions of polymorphic loci observed in the four samples were: $29.93 \%$ (S1), $31.97 \%$ (S2), $23.81 \%$ (S3) and $38.77 \%$ (S4). The average heterozygosity within sampling localities ranged from 0.1230 to 0.1526 and unbiased genetic distances ranged from 0.0253 to 0.0445 . AMOVA partitioned $90.85 \%$ of the total variation within samples and $9.15 \%$ among samples. Excepting for the sample pair S1-S2 $\left(\phi_{S T}=0.02784 ; p>0.05\right)$, all others pairwise $\phi_{S T}$ values were significantly greater than zero, indicating moderate genetic differentiation among catfish samples from four localities. The relative low levels of genetic variation detected in all groups studied could be related to different factors, including the sedentary habit of these fish, which can be eroding the genetic variation of $H$. ancistroides from each locality.
\end{abstract}

Key words: Loricariid fish, genetic diversity, RAPD, Siluriformes.

Received: August 22, 2007; Accepted: April 18, 2007.

\section{Introduction}

In the last decades the conservation of the genetic diversity has emerged as one of the central issues in conservation biology (Bickham et al., 2000) considering its value for the sustainability of populations (Solé-Cava, 2001; Avise 2004). Simultaneously, advances in molecular techniques increased the availability of different DNA-based markers, which have become efficient tools in conservation genetic studies (Haig, 1998; Sunnucks, 2000; Avise, 2004). Random amplified polymorphic DNA (RAPD) is a simple and straightforward PCR-based technique, which uses arbitrary primers for amplification of discrete regions of genome (Williams et al., 1990). RAPD markers have been used to evaluate the genetic diversity in numerous organisms (Cooper, 2000; Ali et al., 2004; Torezan et al., 2005; Bickel et al., 2006) and studies on genetic conservation of fish populations from South American rivers have successfully applied such markers to access the genetic diversity of

Send correspondence to Silvia Helena Sofia. Departamento de Biologia Geral, Centro de Ciências Biológicas, Universidade Estadual de Londrina, Caixa Postal 6001, 86051-990 Londrina, PR, Brazil. E-mail: shsofia@uel.br. different fish species (Almeida et al., 2001, 2003; Dergam et al., 2002; Wasko and Galetti Jr, 2002; Leuzzi et al., 2004; Matoso et al., 2004; Wasko et al., 2004).

Nevertheless, studies of genetic diversity of Neotropical fish populations from urban aquatic ecosystems are still scarce (Sofia et al., 2006). Urban sprawl affects the environment in a myriad of ways at multiple levels of biological organization (Blair, 2004) and considering that cities are typically located near large water bodies, rivers and estuaries, or along coastlines (Melles et al., 2003), more attention should be directed to these aquatic ecosystems in urban areas. Moreover, conservation biologists throughout the world have focused mainly on the protection of "natural" ecosystems, while little importance has been placed on urban areas or urban biodiversity overall (Blair, 1996).

In South American rivers, Hypostomus ancistroides (Ihering 1911) is a common fish species in streams of the upper Paraná basin, in South and Southeastern Brazil (Lemes and Garutti, 2002; Shibatta et al., 2002; Casatti, 2005), its occurrence also being reported in urban streams (Oliveira and Bennemann, 2005). Usually, this fish occupies microhabitats composed of rocks and foliage on the bottom of streams and it behaves typically as an algae-eating fish, 
showing grazing habit and nocturnal activity (LoweMcConnell, 1999; Casatti, 2002). This species belongs to the family Loricariidae (Siluriformes) that includes species ecologically diverse and widely distributed, and commonly known as armored catfishes (Suzuki et al., 2000; Artoni and Bertollo 2001).

Species of Hypostomus are benthic fishes, mainly herbivorous or detritivorous (Casatti, 2002), exhibiting non-migratory and nest/brood guard behavior (Suzuki et $a l ., 2000)$. Such behavioral traits make these fish good candidates for approaches taking into account both genetic variation and genetic structure, since very little gene flow between populations would be expected (Zawadzki et al., 2005). Recently, low levels of genetic variability, assessed by allozyme markers, have been reported for different species of Hypostomus (Paiva et al., 2005).

Despite the large distribution of $H$. ancistroides in Brazilian rivers and its significance in the fish assemblage structure of many Brazilian streams (Casatti, 2005; Oliveira and Bennemann, 2005) little is known about the genetic diversity of this Neotropical species. Particularly in urban streams, studies of population genetic diversity of fishes can provide valuable information for outlining of appropriate conservation actions for the management of these threatened ecosystems and their natural populations. In this context the present research used RAPD markers to assess the genetic variation and population structuring of the catfish $H$. ancistroides from a tropical urban stream located in the metropolitan area of Londrina city, Southern Brazil.

\section{Material and Methods}

\section{Study area}

The Cambé stream and its tributaries constitute the main hydrological basin of Londrina, a city of 500,000 inhabitants, located in the north of the Paraná State, Southern Brazil (Figure 1). This approximately $25 \mathrm{~km}$ long stream crosses the entire city, receiving diffuse and point source discharges of industrial, domestic and agricultural wastes

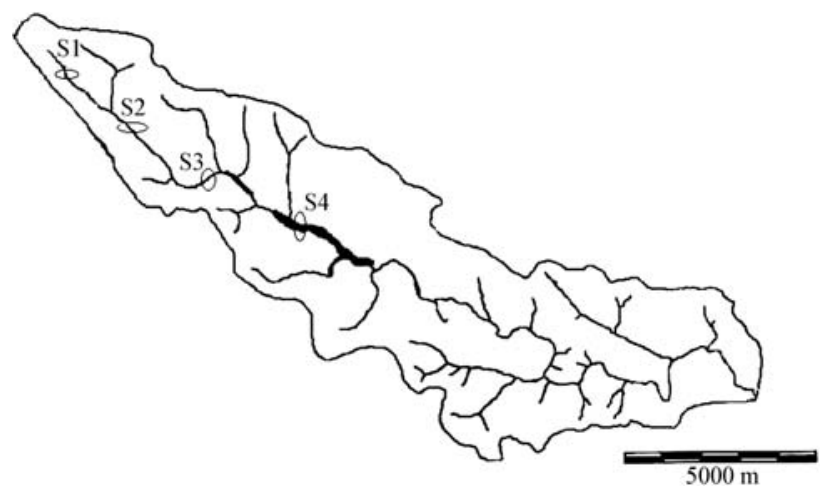

Figure 1 - Location of the study area showing the four sampling sites (S1, S2, S3 and S4) along the Cambé stream, Paraná State, Brazil (Modified from Sofia et al., 2006). along the length of its course (Almeida et al., 2005). Hypostomus ancistroides were caught at four sites along the Cambé stream (S1, S2, S3 and S4) located within the urban area of the city of Londrina (Figure 1). Distances between different sampling sites are shown in Table 1.

\section{Materials and sampling methods}

A total of 46 specimens of $H$. ancistroides were collected using manual fishing tools: 12 at site 1 (S1), 11 at site 2 (S2), 11 at site 3 (S3) and 12 at site 4 (S4). In order to minimize possible biases in the analysis due to the reduced sample size employed, a great effort was made to analyze a large number of loci (Nei, 1978; Kraus and Peakall, 1998).

Fish were brought alive to the laboratory, where they were anaesthetized with benzocaine $\left(0.1 \mathrm{~g}\right.$. $\left.\mathrm{L}^{-1}\right)$, killed by cervical section and then, muscle samples were removed from fish and kept at $-20^{\circ} \mathrm{C}$ until use. After identification some individuals were preserved in ethanol $(70 \%)$ as voucher specimens.

\section{DNA extraction and amplification}

Genomic DNA from the muscle of fish was sampled according to Almeida et al. (2001). DNA concentration was determined in a DyNA Quant 200 fluorometer (Hoefer), using the dye Hoechst 33258, and diluted to a standard DNA concentration of $5 \mathrm{ng} \mu \mathrm{L}^{-1}$. All isolates were then either used immediately or stored at $-20^{\circ} \mathrm{C}$.

Amplifications were performed as described by Sofia et al. (2006). Final reaction volumes were $15 \mu \mathrm{L}$ and contained 15-25 ng of template DNA, $250 \mu \mathrm{M}$ dNTP (Pharmacia Biotech), $0.25 \mu \mathrm{M}$ of ten-nucleotide primer (Operon Technologies, Alameda, CA, USA), $4.5 \mathrm{mM}$ of $\mathrm{MgCl}_{2}$ and $1 \mathrm{U}$ of DNA polymerase in the reaction buffer supplied. Since RAPD technique is sensitive to changes in reaction conditions (e.g. primer, $\mathrm{MgCl}_{2}$, dNTP concentrations etc; Chiappero and Gardenal 2001), the same exact reaction conditions were used for all samples. For the RAPD analysis, 46 decamer oligonucleotides (from kits OPA, OPAM, OPW) were used as random primers in RAPD screening; 11 oligonucleotides that produced a good number of amplified bands and patterns of reproducible fragments were selected for analyses. Control reactions were run with all components except genomic DNA and none of the primers used yielded detectable amplified products in these reactions. DNA amplifications were carried out in a thermal

Table 1 - Geographic distances between the four sampling sites (S1, S2, S3 and S4).

\begin{tabular}{lcccc}
\hline Sites & S1 & S2 & S3 & S4 \\
\hline S1 & $* * *$ & & & \\
S2 & $0.76 \mathrm{~km}$ & $* * *$ & & \\
S3 & $3.71 \mathrm{~km}$ & $2.95 \mathrm{~km}$ & $* * *$ & \\
S4 & $6.99 \mathrm{~km}$ & $6.24 \mathrm{~km}$ & $3.42 \mathrm{~km}$ & $* * *$ \\
\hline
\end{tabular}


cycler (MJ Research PTC-100) and the amplification protocol consisted of $4 \mathrm{~min}$ at $92{ }^{\circ} \mathrm{C}$ followed by 40 cycles of $40 \mathrm{~s}$ at $92^{\circ} \mathrm{C}, 1.5 \mathrm{~min}$ at $40^{\circ} \mathrm{C}$, and $2 \mathrm{~min}$ at $72^{\circ} \mathrm{C}$. The last round of amplification was followed by an additional extension at $72{ }^{\circ} \mathrm{C}$ for $5 \mathrm{~min}$.

Samples of $15 \mu \mathrm{L}$ of amplification products were assayed by electrophoresis on $1.4 \%$ agarose gels with TBE buffer $(0.89 \mathrm{mM}$ Tris, $0.89 \mathrm{mM}$ boric acid, $2 \mathrm{mM}$ EDTA $\mathrm{pH}$ 8.3) diluted 1:20 (v:v), run at $3 \mathrm{~V} \cdot \mathrm{cm}^{-1}$ and stained with ethidium bromide. Agarose gel images were documented under UV light using the Kodak Electrophoresis Documentation and Analysis System (EDAS) 290, and scored visually for band presence and absence.

\section{RAPD analysis}

RAPD marker profiles were determined by direct comparison of the amplified electrophoretic profiles of DNA from each individual, and each band was analyzed as a binary variable (band presence or absence). Comparative analyses were carried out by placing all samples from the four sites on the same gel, for intra and inter-sample analyses. Only RAPD bands that could be scored unequivocally were considered in the analyses.

The RAPD technique generally produces dominant multilocus markers, but can also generate co-dominant markers which most probably arise from small insertions or deletions inside the amplified region (Williams et al., 1990). Statistical methods developed for co-dominant markers have been modified for use with RAPD markers. For the purpose of this study, each locus was treated as a two-allele system, with only one of the alleles per locus being amplifiable by PCR. It was also assumed that marker alleles from different loci did not comigrate to the same position on a gel, and that populations were under the Hardy-Weinberg equilibrium (Lynch and Milligan, 1994). Also, to avoid distortion of results due to problems regarding reproducibility (Williams et al., 1990), only reproducible patterns were included in the data analysis. In the present study, reproducibility of the results was tested through additional RAPD reactions and no variation was found.

The TFPGA 1.3 software (Miller, 1997) was used in the following analyses: i) genetic variability estimated by the proportion of polymorphic loci $(\overline{\mathrm{P}})$, using the $95 \%$ cut-off criterion; ii) average heterozygosity $(\mathrm{He})$; iii) genetic diversity determined using the Shannon's index $\left(I_{S h}\right)$; iv) unbiased genetic distance and identity (Nei, 1978); v) a dendrogram based on the genetic distance-values between four sample pairs and a bootstrap analysis (1000 permutations) to test the robustness of the produced branches.

To evaluate the apportioning of genetic variation within and among sampling localities, an analysis of molecular variance (AMOVA) was performed using the software Arlequin version 3.0 (Excoffier et al., 2005), which is based on the original AMOVA adapted for dominant data
(Stewart and Excoffier, 1996). Variance components based on a matrix of squared Euclidean distances obtained from RAPD phenotypes were tested statistically by nonparametric permutational procedures using 1000 permutations. Arlequin 3.0 was also used to estimate the genetic diversity based on the index of nucleotide diversity $\left(\pi_{n}\right)$, which is the probability that two randomly chosen homologous nucleotides are different (Excoffier et al., 2005). To examine the relationship between genetic distance and the $\phi_{S T}$ values found for different sample pairs, the Spearman coefficient was used.

Finally, RAPD data were analyzed using the NTSYS-pc (Numerical Taxonomy and Multivariate Analysis System) package (Rohlf, 2000) to determine the similarities among individuals. Similarities were estimated using the Jaccard's $(J)$ coefficient.

\section{Results}

The 11 primers used for the H. ancistroides RAPD analysis reproducibly amplified 147 loci, 76 (51.7\%) of which were polymorphic. The result obtained with one of these primers, OP-W18, is shown in Figure 2. The number of fragments per primer ranged from 6 for OP-W6 to 24 for OP-AM9 with a mean number of 13.36 bands per primer.

Table 2 shows the different estimates of genetic variation obtained for the samples of $H$. ancistroides from sites S1, S2, S3 and S4 at Cambé stream. The lowest measure of genetic variation was found for fish from site 3 . All measures of genetic variation used corroborated in detecting the lowest estimation of genetic variation for sample from site 3 . Except for nucleotide diversity $\left(\pi_{n}\right)$, the other three estimates indicated the highest level of genetic variation for sample from site $4: \overline{\mathrm{P}}(38.77 \%)$, average $\mathrm{He}(0.1526)$ and $I_{S h}$ (0.2230).

Coefficients of variation for errors associated with genetic similarity among $H$. ancistroides genotypes, estimated by Jaccard coefficient, were calculated for different numbers of RAPD markers (Coelho, 2000). In the array between 95 and 147 amplified fragments, the coefficients of variation for errors showed little variation, ranging from 4.98 to $3.97 \%$ (Figure 3), indicating that further increase in the number of markers probably would not result in an important reduction in the coefficient of variation. Additionally, values of coefficients of variation below $5 \%$ can be considered acceptable for this type of analysis.

Genetic similarity among all individuals estimated by Jaccard's coefficient varied from 0.722 (individuals 12 from site 1, and 3 from site 2) to 0.951 (individuals 7 and 8 from site 1). At site 1 , the values of similarity among pairs of individuals ranged from 0.724 to 0.951 ; at site 2 , from 0.763 to 0.933 ; at site 3 , from 0.830 to 0.944 , and at site 4 , from 0.761 to 0.902 . Mean genetic similarity and standard deviation (SD) of the samples from sites 1, 2, 3 and 4 were, respectively: $0.860(\mathrm{SD}=0.045), 0.841(\mathrm{SD}=0.036)$, 


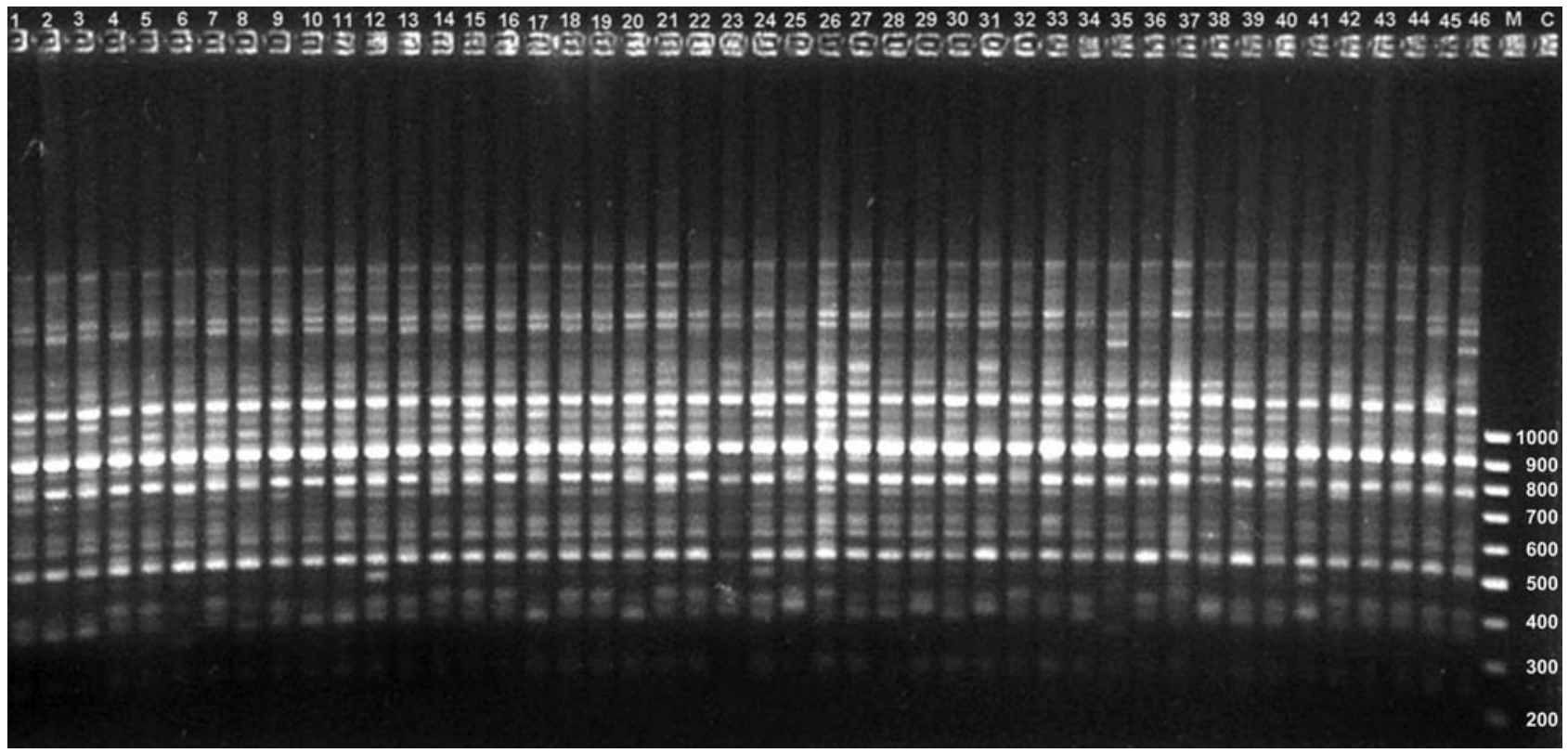

Figure 2 - RAPD profiles, amplified with primer OP-W18, of $46 \mathrm{H}$. ancistroides collected from sites S1 to S4. Column M, molecular weight marker (Biotools) in bp; Column C, control; columns 1-12, fish collected at site 1; columns 13-23, fish collected at site 2; columns 24-34, fish collected at site 3; columns 35-46, fish collected at site 4

Table 2 - Proportion of polymorphic loci $(\overline{\mathrm{P}})$, average heterozygosity $(H e)$, Shannon's diversity index $\left(I_{S h}\right)$ and nucleotide diversity $\left(\pi_{n}\right)$ for the samples of $H$. ancistroides from sites S1, S2, S3 and S4 on the Cambé stream; ( ) = standard deviation.

\begin{tabular}{lcccc}
\hline Samples & $\overline{\mathrm{P}}$ & $H e$ & $I_{S h}$ & $\pi_{n}$ \\
\hline S1 & $29.93 \%$ & 0.1230 & $0.1797( \pm 0.2714)$ & $0.1251(0.0690)$ \\
S2 & $31.97 \%$ & 0.1398 & $0.2038( \pm 0.2853)$ & $0.1379(0.0759)$ \\
S3 & $23.81 \%$ & 0.1022 & $0.1488( \pm 0.2584)$ & $0.0906(0.0502)$ \\
S4 & $38.77 \%$ & 0.1526 & $0.2230( \pm 0.2835)$ & $0.1270(0.0700)$ \\
\hline
\end{tabular}

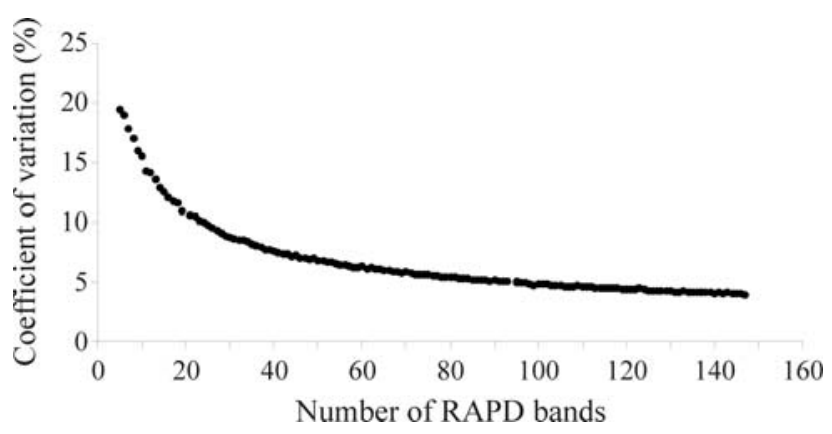

Figure 3 - Relationship between different number of RAPD bands and coefficients of variation (\%) for errors associated with genetic similarity among $H$. ancistroides genotypes, based on Jaccard coefficient.

$0.894(\mathrm{SD}=0.021)$ and $0.804(\mathrm{SD}=0.033)$, while the mean values of genetic similarities between pairs of samples were: $\mathrm{S} 1-\mathrm{S} 2=0.845(\mathrm{SD}=0.039) ; \mathrm{S} 1-\mathrm{S} 3=0.861$ $(\mathrm{SD}=0.039) ; \mathrm{S} 1-\mathrm{S} 4=0.833(\mathrm{SD}=0.042) ; \mathrm{S} 2-\mathrm{S} 3=0.856$ $(\mathrm{SD}=0.030) ; \mathrm{S} 2-\mathrm{S} 4=0.826(\mathrm{SD}=0.032)$, and $\mathrm{S} 3-\mathrm{S} 4=0.852(\mathrm{SD}=0.028)$.
Estimates of Nei's (1978) pairwise unbiased genetic distances for $H$. ancistroides ranged from 0.0253 to 0.0445 (Table 3), and unbiased genetic identity varied from 0.9565 to 0.9750 . The highest value of genetic distance $(0.0445)$ was found between fish from sites 2 and 3 .

AMOVA partitioned $90.85 \%$ of the total variation within sampling localities, and $9.15 \%\left(\phi_{S T}=0.09153\right)$ among samples (Table 3). Except for the pairwise S1-S2 $\left(\phi_{S T}=0.02784 ; \mathrm{p}>0.05\right)$, the pairwise $\phi_{S T}$ values were all significantly greater than zero at $p<0.0001$ (Table 4 ), indicating some divergence between different sample pairs of $H$ ancistroides analyzed. Cluster analysis based on the genetic distance (Nei, 1978) among H. ancistroides from four localities grouped sites S1 and S2 (0.0253), and sites S3 and S4 (0.0330) together, supported by bootstrap values of $83.1 \%$ and $59.8 \%$, respectively (Figure 4 ). The comparison of levels of genetic distance with the $\phi_{S T}$ differences between sample pairs showed no significant relationship between these genetic parameters $\left(r_{S}=-0.143 ; p>0.05\right)$.

\section{Discussion}

In a recent review Ali et al. (2004) emphasized the applicability of RAPDs for population studies of fish, their effectiveness in detecting polymorphism between and among different fish populations, and the establishment of genetic relationships among fish populations. In the current study, the values of $\overline{\mathrm{P}}$ observed in $H$. ancistroides ranged from $23.81 \%$ to $38.77 \%$; these values were lower than those detected for a number of Neotropical fish species from the Paraná River basin which showed values of $\overline{\mathrm{P}}$ estimated by RAPD technique from 51.9 to $75.0 \%$ (Almeida et al., 2001, 
Table 3 - Analysis of molecular variance (AMOVA) using 147 RAPD loci, partitioning genetic variation within and between samples of $H$. ancistroides from four sites on the Cambé stream.

\begin{tabular}{lrccc}
\hline $\begin{array}{l}\text { Source of } \\
\text { variation }\end{array}$ & df & $\begin{array}{c}\text { Sum of } \\
\text { squares }\end{array}$ & $\begin{array}{c}\text { Variance } \\
\text { components }\end{array}$ & $\begin{array}{c}\% \text { of } \\
\text { variation }\end{array}$ \\
\hline Among samples & 3 & 32.579 & 0.50704 & 9.15 \\
Within samples & 42 & 211.356 & 5.03229 & 90.85 \\
Total & 45 & 243.935 & 5.53933 & \\
\hline
\end{tabular}

Fixation index - $\phi_{S T}: 0.09153$.

Table 4 - Estimation of Nei's (1978) unbiased genetic distance $(D)$ and identity (I), with Lynch and Milligan (1994) correction, between pairs of $H$. ancistroides from four different sites (S1, S2, S3 and S4) on the Cambé stream. AMOVA $\left(\phi_{S T}\right)$ pairwise differences and p-value are also shown.

\begin{tabular}{lcccl}
\hline $\begin{array}{l}\text { Pairwise } \\
\text { samples }\end{array}$ & $D$ & $I$ & $\begin{array}{c}\phi_{S T} \text { pairwise } \\
\text { difference }\end{array}$ & p-value \\
\hline S1-S2 & 0.0253 & 0.9750 & 0.02784 & $>0.05$ \\
S1-S3 & 0.0394 & 0.9614 & 0.10546 & $<0.0001$ \\
S1-S4 & 0.0351 & 0.9655 & 0.11943 & $<0.0001$ \\
S2-S3 & 0.0445 & 0.9565 & 0.05765 & $<0.0001$ \\
S2-S4 & 0.0409 & 0.9599 & 0.10321 & $<0.0001$ \\
S3-S4 & 0.0330 & 0.9676 & 0.12425 & $<0.0001$ \\
\hline
\end{tabular}
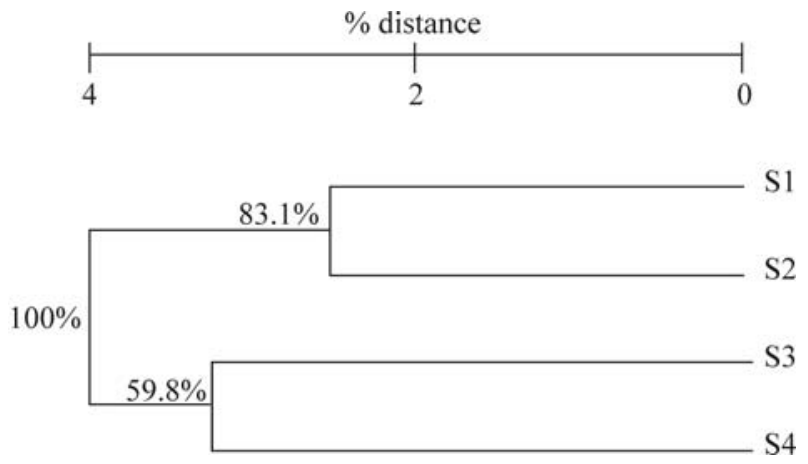

Figure 4 - Dendrogram of genetic dissimilarity (\%), based on Nei's (1978) genetic distance, for $H$. ancistroides populations from sites $\mathrm{S} 1, \mathrm{~S} 2, \mathrm{~S} 3$ and $\mathrm{S} 4$ on the Cambé stream. Numbers at the nodes represent bootstrap generated by 1000 replications.

2003; Leuzzi et al., 2004; Sofia et al., 2006). Although it has been suggested that the forces that regulate the levels of genetic variability of loricariids inhabiting small streams are variable and complex (Zawadzki et al., 2004), the low levels of genetic variation found for this species at Cambé stream could be reflecting, to some extent, an endogamic processes among individuals from each locality since $H$. ancistroides shows a sedentary habit. Also, some authors have attributed low levels of genetic variation in aquatic organisms to the disturbed conditions of streams (Foré et al., 1995; Bickham et al., 2000; Belfiore and Anderson, 2001). In fact, Winkaler et al. (2001) showed that wild fish from the upper reaches of Cambé stream present impaired health and Lemos et al. (2005) demonstrated by the comet assay that its water induces DNA damage. More recently, Camargo and Martinez (2006) showed that the Neotropical fish Prochilodus lineatus confined in these areas presented functional alterations in response to water contamination. However, the present results do not allow drawing any conclusions about this fact, since no reference population was surveyed in this study.

An allozyme genetic variability analysis has revealed the occurrence of a wide variation in heterozygosity $(\mathrm{He})$ values for populations of different Hypostomus species (Zawadzki et al., 2005). Actually, while low $\mathrm{He}$ values (from zero to 0.028 ) have been observed for populations of three species of Hypostomus (Paiva et al., 2005), relatively higher levels of heterozygosity ( $\mathrm{He}=0.082$ and 0.052 ) were reported for populations of $H$. ancistroides from Itaipu Reservoir and Corumbá River (Zawadzki et al., 2005). The levels of $H e$ observed in all samples of $H$. ancistroides from Cambé stream were even higher (0.1022 to 0.1526$)$ than those mentioned by Zawadzki et al. (2005). However, this discepancy could be partially explained by the inherent differences between RAPD and allozyme techniques, since allozymes detect only about $1 / 3$ of actual amino acid variation and do not detect synonymous changes, while RAPDs have the potential to detect practically all changes, independent of whether they cause amino acid changes or not.

In this study, the values of genetic similarity estimated between pairs of catfish from the same site, as well as between sample pairs of catfish from different sites were elevated ( 0.722 to 0.951$)$. These high values of similarities might be reflecting the low levels of genetic variation showed by different catfish populations analyzed here.

According to Wright (1978), theoretical values of $F_{S T}$ ranging from 0.05 to 0.15 are indicative of moderate genetic differentiation between pairs of populations. On the basis of the $\phi_{S T}$ estimates and at the level of sampling attained in this study, except for the samples of $H$. ancistroides from sites S1 and S2 which did not show differentiation between them $\left(\phi_{S T}=0.02784 ; \mathrm{p}>0.05\right)$, all other sample pairs were significantly divergent among each other, showing moderate genetic differentiation values (Table 4). Apparently, these findings are in accordance with the prediction of Zawadzki et al. (2005) who pointed out that limited gene flow would be expected between populations of Hypostomus because of their sedentary habit.

The highest value of Nei's unbiased genetic distance (Nei, 1978) found between the pairwise comparison S2-S3 did not coincide with the $\phi_{S T}$ estimates which was the lowest significant value of $\phi_{S T}$ detected (Table 4). However, this discrepancy between two parameters could be due to intrinsic differences in these genetic estimates. Considering that RAPDs are generally dominant markers, this characteristic prevents direct estimations of allele frequency, and can bias calculations of genetic diversity and population differentiation (Lynch and Milligan, 1994; Isabel et al., 
1999). Thus, the analysis of molecular variance (AMOVA) which is not influenced by the dominant nature of RAPD, has been chosen by several authors for investigating the partitioning of dominant marker variation (Ross et al., 1999; Cooper, 2000; Díaz et al., 2001).

The expansion of urban areas worldwide makes our understanding of aquatic ecosystems in urban environments extremely important. Genetic approaches offer powerful tools for examining the current status of populations, for inferring the history of population changes, and for anticipating future population directions (Belfiore and Anderson, 2001). Thus, the present results may well contribute to future management of the populations of $H$. ancistroides from Cambé stream.

\section{Acknowledgments}

The authors are grateful to Dr. Oscar A. Shibatta for his valuable help in fish identification, to the anonymous referees who contributed with valuable suggestions and IBAMA (Instituto Brasileiro do Meio Ambiente e Recursos Naturais Renováveis) for permission to collect fish. This study was supported by grants from the Brazilian research funding institutions $\mathrm{CNPq}$ and Fundação Araucária to C.B.R. Martinez. B.A. Galindo and F.M. Paula thank CNPq for their fellowship.

\section{References}

Ali BA, Huang T-H, Qin Da-N and Wang X-M (2004) A review of random amplified polymorphic DNA (RAPD) markers in fish research. Rev Fish Biol Fish 14:443-453.

Almeida FS, Fungaro MHP and Sodré LMK (2001) RAPD and isoenzyme analysis of genetic variability in three allied species of catfish (Siluriformes, Pimelodidae) from the Tibagi river, Brazil. J Zool 253:113-120.

Almeida FS, Sodré LMK and Contel EPB (2003) Population structure of Pimelodus maculatus (Pisces, Siluriformes) from the Tietê and Paranapanema Rivers (Brazil). Genet Mol Biol 26:301-305.

Almeida JS, Meletti PC and Martinez CBR (2005) Acute effects of sediments taken from an urban stream on physiological and biochemical parameters of the neotropical fish Prochilodus lineatus. Comp Biochem Physiol C 140:356363.

Artoni RF and Bertollo LAC (2001) Trends in the karyotype of Loricariidae fish (Siluiriformes). Hereditas 134:201-210.

Avise JC (2004) Molecular Markers, Natural History and Evolution. 2nd ed. Sinauer Associates, Sunderland, 684 pp.

Belfiore NM and Anderson SL (2001) Effects of contaminants on genetic patterns in aquatic organisms: A review. Mutat Res 489:97-122.

Bickel TO, Brühl CA, Gadau JR, Hölldobler B and Linsenmair KE (2006) Influence of habitat fragmentation on the genetic variability in leaf litter ant populations in tropical rainforests of Sabah, Borneo. Biodivers Conserv 15:157-175.

Bickham JW, Sandhu S, Hebert PDN, Chickhi L and Athwal R (2000) Effects of chemical contaminants on genetic diver- sity in natural populations: Implications for biomonitoring and ecotoxicology. Mutat Res 463:33-51.

Blair RB (1996) Land use and avian species diversity along an urban gradient. Ecol Appl 6:506-519.

Blair R (2004) The effects of urban sprawl on birds at multiple levels of biological organization. Ecol Soc 9:2. http://www.ecologyandsociety.org/vol5/iss5/art2.

Camargo MMP and Martinez CBR (2006) Biochemical and physiological biomarkers in Prochilodus lineatus submitted to in situ tests in an urban stream in southern Brazil. Environ Toxicol Pharmacol 21:61-69.

Casatti L (2002) Alimentação dos peixes em um riacho do Parque Estadual Morro do Diabo, bacia do alto Rio Paraná, sudeste do Brasil. Biota Neotrop 2:1-14.

Casatti L (2005) Fish assemblage structure in a first order stream, southeastern Brazil: Longitudinal distribution, seasonality, and microhabitat diversity. Biota Neotrop 5:1-8.

Chiappero MB and Gardenal CN (2001) Inheritance of random amplified polymorphic DNA (RAPD-PCR) markers and their use in population studies of Calomys musculinus (Rodentia, Muridae), the reservoir of Argentine Hemorrhagic Fever. Hereditas 135:85-93.

Coelho ASG (2000) BOOD: Software de avaliação de dendrogramas baseados em estimativas de distâncias/similaridades genéticas através do procedimento de bootstrap. UFG, Goiânia.

Cooper ML (2000) Random amplified polymorphic DNA analysis of southern brown bandicoot (Isoodon obesulus) populations in Western Australia reveals genetic differentiation related to environmental variables. Mol Ecol 9:469-479.

Dergam JA, Paiva SR, Schaeffer CE, Godinho AL and Veira F (2002) Phylogeography and RAPD-PCR variation in Hoplias malabaricus (Bloch, 1794) (Pisces, Teleostei) in southeastern Brazil. Genet Mol Biol 25:379-387.

Díaz V, Muñiz M and Ferrer E (2001) Random amplified polymorphic DNA and amplified fragment length polymorphism assessment of genetic variation in Nicaraguan populations of Pinus oocarpa. Mol Ecol 10:2593-2603.

Excoffier L, Laval G and Scheneider S (2005) Arlequin ver 3.0: An integrated software package for population genetics data analysis. Evol Bioinform Online 1:47-50.

Foré AS, Guttman SI, Bailer AJ, Altfater DJ and Counts BV (1995) Exploratory analysis of population genetic assessment as a water quality indicator. I. Pimephales notatus. Ecotoxicol Environ Saf 30:24-35.

Hadrys H, Balick M and Schierwater B (1992) Applications of random amplified polymorphic DNA (RAPD) in molecular ecology. Mol Ecol 1:55-63.

Haig SM (1998) Molecular contributions to conservation. Ecology 79:413-425.

Isabel N, Beaulieu J, Thériault P and Bousquet J (1999) Direct evidence for biased gene diversity estimates from dominant random amplified polymorphic DNA (RAPD) fingerprints. Mol Ecol 8:477-483.

Krauss SL and Peakall R (1998) An evaluation of the AFLP fingerprinting technique for the analysis of paternity in natural populations of Persoonia mollis (Proteaceae). Aust J Bot 46:533-546.

Lemes EM and Garutti V (2002) Ecologia da ictiofauna de um córrego de cabeceira do Alto Rio Paraná, Brasil. Iheringia 92:69-78. 
Lemos NG, Dias AL, Silva-Souza AT and Mantovani MS (2005) Evaluation of environmental waters using the comet assays in Tilapia rendalli. Environ Toxicol Pharmacol 19:197-201.

Leuzzi MSP, Almeida FS, Orsi ML and Sodré LMK (2004) Analysis by RAPD of the genetic structure of Astyanax altiparanae (Pisces, Characiformes) in reservoirs on the Paranapanema river Brazil. Genet Mol Biol 27:355-362.

Lowe-McConnell RH (1999) Estudos Ecológicos em Comunidades de Peixes Neotropicais. EDUSP, São Paulo, 534 pp.

Lynch M and Milligan BG (1994) Analysis of population structure with RAPD markers. Mol Ecol 3:91-99.

Matoso DA, Artoni RF and Galetti Junior PM (2004) Genetic diversity of the small characid fish Astyanax sp., and its significance for conservation. Hydrobiologia 527:223-225.

Melles S, Glenn S and Martin K (2003) Urban bird diversity and landscape complexity: Species - Environment associations along a multiscale habitat gradient. Conserv Ecol 7:5.

Miller MP (1997) Tools for population genetic analysis (TFPGA) 1.3: A Windows program for the analysis of allozyme and molecular population genetic data. http://www. markgeneticsoftware.net/.

Nei M (1978) Estimation of average heterozygosity and genetic distance from a small number of individuals. Genetics 89:583-590.

Oliveira DC and Bennemann ST (2005) Ictiofauna, recursos alimentares e relações com as interferências antrópicas em um riacho urbano no sul do Brasil. Biota Neotrop 5:1-13.

Paiva S, Renesto E and Zawadzki CH (2005) Genetic structure of Hypostomus (Teleostei, Loricariidae) from the Ribeirão Maringá, a stream of the upper Rio Paraná basin, Brazil. Genet Mol Biol 28:370-375.

Rohlf FJ (2000) NTSYS-pc: Numerical taxonomy and multivariate analysis system, version 2.1. Exeter Software, Setauket, NY.

Ross KG, Shoemaker DD, Krieger MJB, DeHeer CJ and Keller L (1999) Assessing genetic structure with multiple classes of molecular markers: A case study involving the introduced fire ant Solenopsis invicta. Mol Biol Evol 16:525-543.

Shibatta OA, Orsi ML, Benemann ST and Silva-Souza AT (2002) Diversidade e distribuição de peixes na bacia do rio Tibagi. In: Medri ME, Bianchini E, Shibatta AO and Pimenta JA (eds) A Bacia do Rio Tibagi. Edição dos Editores, Londrina, pp 403-423.

Sofia SH, Silva CRM, Galindo BA, Almeida FS, Sodré LMK and Martinez CBR (2006) Population genetic structure of Astyanax scabripinnis (Teleostei, Characidae) from an urban stream. Hydrobiologia 553:245-254.
Solé-Cava AJ (2001) Biodiversidade molecular e genética da conservação. In: Matioli SR (ed) Biologia Molecular e Evolução. Holos, Ribeirão Preto, pp 172-192.

Stewart CN and Excoffier L (1996) Assessing population genetic structure and variability using RAPD data: Application to Vaccinium macrocarpum (American cranberry). J Evol Biol 9:153-171.

Sunnucks P (2000) Efficient genetic markers for population biology. Trends Ecol Evol 15:199-203.

Suzuki HI, Agostinho AA and Winemiller KO (2000) Relationship between oocyte morphology and reproductive strategy in loricariid catfishes of the Paraná River, Brazil. J Fish Biol 57:791-807.

Torezan JMD, Souza RF, Ruas PM, Ruas CF, Camargo EH and Vanzela ALL (2005) Genetic variability of pre and pos-fragmentation cohorts of Aspidosperma polyneuron Muell. Arg. (Apocynaceae). Braz Arch Biol Techn 48:171-180.

Wasko AP and Galetti Jr PM (2002) RAPD analysis in the Neotropical fish Brycon lundii: Genetic diversity and its implications for the conservation of the species. Hydrobiologia 474:131-137.

Wasko AP, Martins C, Oliveira C, Senhorini JA and Foresti F (2004) Genetic monitoring of the Amazonian fish matrinchã (Brycon cephalus) using RAPD markers: Insights into supportive breeding and conservation program. J Appl Ichthyol 20:48-52.

Williams JGK, Kubelik AR, Livak KL and Tingey SV (1990) DNA polymorphism amplified by arbitrary primers are useful as genetic markers. Nucleic Acids Res 18:6531-6535.

Winkaler EU, Silva AG, Galindo HC and Martinez CBR (2001) Biomarcadores histológicos e fisiológicos para o monitoramento da saúde de peixes de ribeirões de Londrina, Estado do Paraná. Acta Scient 23:507-514.

Wright S (1978) Evolution and the Genetics of Populations, v. 4. Variability Within and Among Natural Populations. University of Chicago Press, Chicago, 590 pp.

Zawadzki CH, Renesto E, Paiva S and Lara-Kamei CS (2004) Allozyme differentiation of four populations of Hypostomus (Teleostei, Loricariidae) from Ribeirão Keller, a small stream in the Rio Paraná basin, Brazil. Genetica 121:251257.

Zawadzki CH, Renesto E, Paiva S and Lara-Kamei CS (2005) Allozyme relashionships in hypostomines (Teleostei, Loricariidae) from the Itaipu Reservoir, Upper Rio Paraná basin, Brazil. Genetica 123:271-283.

Associate Editor: Maria Iracilda Sampaio

License information: This is an open-access article distributed under the terms of the Creative Commons Attribution License, which permits unrestricted use, distribution, and reproduction in any medium, provided the original work is properly cited. 